\title{
Kithul flour (Caryota urens) as new plant origin Gelatinizing agent with a product development of fruit-based dessert
}

\section{J A A C Wijesinghe ${ }^{1 *}$, I. Wicramasinghe ${ }^{2}$, K.H Saranandha ${ }^{3}$}

${ }^{1,2}$ Department of Food Science \& Technology, Faculty of Applied Sciences, University of Sri Jayewardenepura, Gangodawila, Nugegoda, SRI LANKA

${ }^{3}$ Head of the Department, Food Research Unit, Gannoruwa, Department of Agriculture, SRI LANKA

*Corresponding Contact:

Email: lucky.research@yahoo.com

Cell Phone: +94777717798

\begin{abstract}
Kithul (Caryota urens) flour has better gel-forming ability among other flour in the food industry. This study aimed to utilization of Kithul flour as substitute to existing plant origin gelling agent for food applications of vegetarians .Fruit based desserts can be produced using Kithul flour as the gelatinizing agent. This wood apple based dessert is the best example for that. The selected best sample with 1:1.5 flour: fruit pulp ratio, gave acceptable results as SLS standards 586:1982 and SLS standards 729:1985 for the tests done (sensory evaluation, Microbial analysis, $\mathrm{pH}$ and $\mathrm{brix}^{\mathrm{O}}$ ). According to the shelf life studies the product with added preservatives can be kept at room temperature for 2 months in acceptable condition (sensory and microbiologically) .

According to the proximate analysis energy generation from $100 \mathrm{~g}$ of the product is $262.28 \mathrm{Kcal}$. Compared to fruit jellies which prepared by pectin as plant-based gelling agent, Kithul dessert has more nutrients, and considerable amount of minerals with less carbohydrate and low calorie. This is a cost effective product which can earn considerable profit by marketing as a nutritious dessert by combination of high swelling flour with seasonal fruit.
\end{abstract}

Keywords: Gelatinizing Agents, Kithul Flour, Fruit based Dessert, vegetarians, Caryota urens, Food product development, Wood apple

\section{INTRODUCTION}

Gelatin can be made from many different sources of collagen, and all major sources are of animal origin (Shyni etel, 2014). Only few non-animal origin gelatinizing agents are available in the world, such as seaweed and pectin (Institute of Food Research). Gelatin can be used as either a processing aid or an ingredient (GMIA, 2012). Food habits in the world have started to change in the recent past, more people are becoming vegetarians and there is an increasing demand for vegetarian food. Therefore animal-based products and animal origin ingredients are rejected by a group of people in the society (Morrison, 
1999). On the other hand raw material for production of gelatin from fish has failed to gain consumer's trust because of the allergic factor (Rammaya etel, 2012).

Since gelatin, which is the main gelatinizing agent used in food industry, is of animal origin, there is a desperate need for a non-animal origin substitute to meet the increasing demand. Researchers are trying to study different ingredients to produce stable and palatable gelatinizing agents that can meet market requirements. Kithul flour, which is a low-cost and nutritious alternative for gelatin, brings the solution for this requirement. People believe that the intake of Kithul products is healthier (Seneviratne, 2011). A porridge prepared from Kithul flour which is called as "Kithul kenda" is prescribed by Ayurvedic physicians to treat gastric ulcers, migraine headaches and rheumatic swellings (Seneviratne, 2011). Current Indian food industry's keen attention is being focused on the plant resources as uncommon food resources in the wild (Rajyalakshmi, 2004) for their potential in new product development. Especially Kithul flour has major attention as it is equal in quality to one of the commercially best sago obtained from Metroxylon sagu (Wealth of India).

Based on these factors there is growing demand for Kithul products in local as well as export market. But it is difficult to find high quality Kithul products in the market due to lack of quality control measures (Seneviratne, 2011). However there is great potential to improve this industry up to export of products specially as gelatinizing agents for vegetarians. The main objective of this study was to find out the possibility of using Kithul flour as a gelatinizing agent in the food industry. As native (Morton, 1987), underutilized fruit with highly acceptable taste (Pansare) and number of health benefits, Wood apple (Limonia acidissima) be a better combination for this dessert. Developing a value added ready to eat dessert with organic, underutilized ingredients will be beneficial for expansion of the food industry as well as empower the rural economy in Sri Lanka with Kithul industry.

On the other hand fruit-based product development plays an important role in the preservation and better utilization of fruits and vegetables in order to avoid the superfluity and utilize the excess during the off-season. It is useful to introduce novel product to extend storage life for better distribution for utilization in the off-season. Wood apple (Limonia acidissima) will have better utilization with mass production of this kind dessert products which could distribute with considerable time of shelf life.

\section{Materials AND Methods}

Procurement of samples: Five hundred grams of Kithul flour were purchased at random from three households from Kandy district. Fully ripe wood apple (Limonia acidissima) with a sweet smell was purchased from Kandy area. Sugar, salt and potassium sorbate were purchased from a commercial market in Colombo.

Sample preparation \& Formulation: Kithul flour samples were sifted through a $355 \mu \mathrm{m}$ sieve. Wood apple fruit flesh was scooped out using a spoon and mixed well with water as nearly double the weight of wood apple flesh. Through the mixing process pulp was separated using a muslin cloth. Weighed Kithul flour, sugar, and salt were mixed with fruit pulp according to the ratios given in Table 1 to obtain three samples with Kithul flour: fruit pulp ratios as 1:1, 1:1.5 and 1:2. The mixture was heated up to $80-90^{\circ} \mathrm{C}$ until it gelatinized. Mixing was the essential step throughout the heating process. The gelatinized mixture was removed from the flame, weighed potassium sorbate (330 ppm) was added, and mixed well. Then the dessert was filled into cleaned cups.

Proximate analysis \& Sensory evaluation: Proximate analysis was carried out for the best sample selected by sensory evaluation studies. Moisture, total fat, protein $(\mathrm{N} \times 6.25)$, ash and crude fiber content were determined according to AOAC (2000) methods. Carbohydrate 
contents were determined by difference sum of above categories. Mineral content was determined by dry ashing method (AOAC 2000). The ash was dissolved in conc. $\mathrm{HCl}$, filtered and dilute with distilled water. Prepared samples were analyzed with a standard series of solutions by Atomic Absorption Spectrophotometer (Thermo Scientific ICE3000 series). Samples were analyzed for $\mathrm{pH}$ (HANNA $\mathrm{pH}$ meter) and Brix value (hand refractometer). The Sensory evaluation was conducted to select the best recipe. Eight trained panelists and twelve untrained panelists evaluated the organoleptic properties (colour, odour, appearance, flavour, acidity, and overall acceptability) of samples using a 7-point hedonic scale.

Shelf life studies: Shelf life studies were carried out at four different storage conditions: with and without preservatives at room temperature, and with and without preservative under refrigerated conditions $\left(5^{\circ} \mathrm{C}\right)$. Yeast and mold tests (AOAC 997.02) were carried out at $0,1,3,5,10,15,20,25,30,60,80$ and 90 days of storage.

Statistical Analysis: Results were analyzed by Friedman test at 95\% level of significance using computer aided MINITAB 17 Statistical Analysis Package.

\section{RESULTS AND DISCUSSION}

According to the sensory evaluation tests, around $80 \%$ of the panelists preferred the sample prepared using 1:1.5 ratio of flour: fruit pulp over other two treatments (Fig.1). The recipe for this sample is given in Table 1. Chemical composition of the product is given in Table 2. Figure 2 shows the results obtained for microbiological evaluation of the products at different storage conditions. Potassium sorbate (E 202) was used according to the suitability of acidic medium. Though the used amount of Potassium sorbate (E202) was $330 \mathrm{ppm}$, it could be increased up to 1000 ppm according to the food act (Nutrition $\mathcal{E}$ Uva Wellassa Development, 2004) for further extension of shelf life.

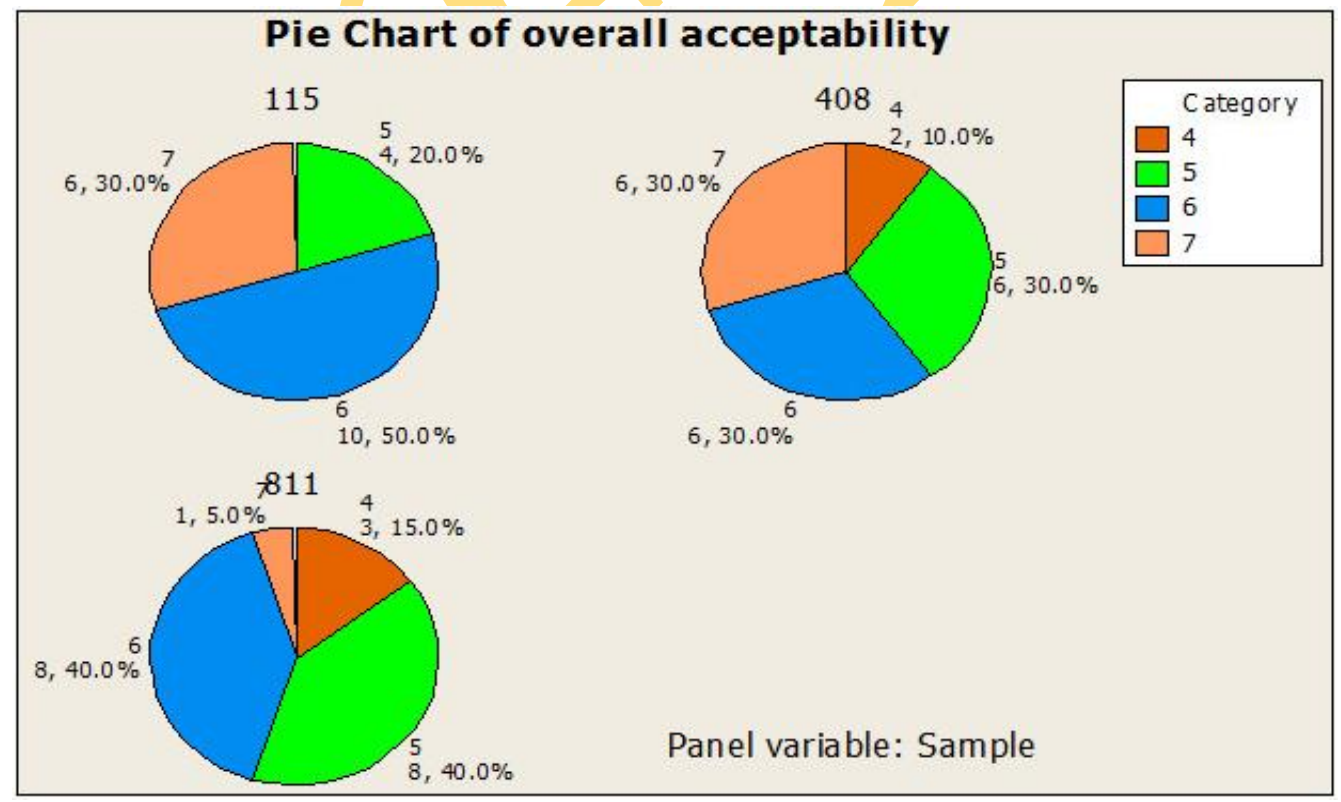

Figure 1.Pie chart of overall acceptability Sample No: 408 for 1:1 ratio of flour: fruit pulp

Sample No: 115 for 1:1.5 ratio of flour: fruit pulp

Sample No: 811for 1:2 ratio of flour: fruit pulp 
The critical point of this research project was to select a suitable fruit as the base of this dessert which align with one of this research objectives as minimum usage of artificial ingredients. After considering several factors, wood apple was selected as the fruit base for this product.

The main reason for selection was the colour of the fruit. Kithul flour gives a brown colour after the heat treatment. If a fruit base with same colour is used, artificial colours are not required to mask unpleasant colours or differences of colour in the final product. Furthermore, wood apple has a pleasant aroma and flavour which can enhance the flavor of the product without adding any artificial flavour enhancers.

Its sweet-sour taste is very acceptable among consumers. According to the Ayurvedic medicine wood apple has laxative effects (Pansare). The foods made with minimum usage of artificial chemicals are considered as healthier, so wood apple was selected as the fruit base. Other reason is wood apple is an acidic fruit. Foods with $\mathrm{pH}$ values below 4 have extended shelf lives because low $\mathrm{pH}$ retards the growth of bacteria and many yeasts and moulds.

Table1: Selected Recipe

\begin{tabular}{ll}
\hline Material & Amount \\
Kithul (Caryota urens) flour & $25 \mathrm{~g}$ \\
Wood Apple ( Limonia acidissima) pulp & $37.5 \mathrm{~g}$ \\
Water & $250 \mathrm{ml}$ \\
Sugar (Sucrose) & $75 \mathrm{~g}$ \\
Salt (Sodium cholide) & $5 \mathrm{~g}$ \\
Potassium sorbate $\left(\mathrm{C}_{6} \mathrm{H}_{7} \mathrm{KO}_{2}\right)$ & $0.129 \mathrm{~g}$ \\
\hline Total Amount & $\mathbf{3 9 2 . 6 3} \mathbf{g}$ \\
\hline
\end{tabular}

By giving high sugar concentration and low $\mathrm{pH}$, a product's shelf life can be increased (AOAC, 2000) based on the principals of osmosis. Potassium sorbate was used as preservative which is more effective than sodium benzoate and sodium or calcium propionate specially in acidic medium as yeast and mold inhibitor (APAC Chemical Corporation). On the other hand potassium sorbate is GRAS (Generally Recognized As Safe) for use in foods, which have been approved as food preservatives by the U.S. food \& Drug Administration. Based on these factors as well as a food additive/preservative since 1955, Potassium sorbate has selected as best preservative for this product development (APAC Chemical Corporation).

As the final finding based on this study was Fruit-based desserts can be formulated successfully using Kithul flour as the gelatinizing agent. Microbiological quality and the Brix $^{\circ}$ value of the selected best sample (1:1.5 ratio of flour: fruit pulp) conform to SLS standards 729:1985 (SLS 729:1985) and SLS standards 586:1982 (SLS 586:1982). According to the shelf life studies, the product with preservatives could be kept at room temperature for 2 months in acceptable conditions (sensory and microbiological, Figure 2).

The moisture content of a product plays a considerable role in the textural properties as well as shelf life. This dessert has contained $34.07 \%$ of moisture while protein and total fat contents were $0.14 \%$ and $0.12 \% \%$ respectively. Crude fiber content was $0.14 \%$. Carbohydrate content has calculated by difference of other proximate parameters as per the Table 2. Because of the calculation method carbohydrate content depend on other parameters, such as moisture content, ash, crude fiber etc. which has showed $65 \%$ carbohydrate content. 
Line Plot of Acceptablel leve for Yeast and mold test of samples with different treatments
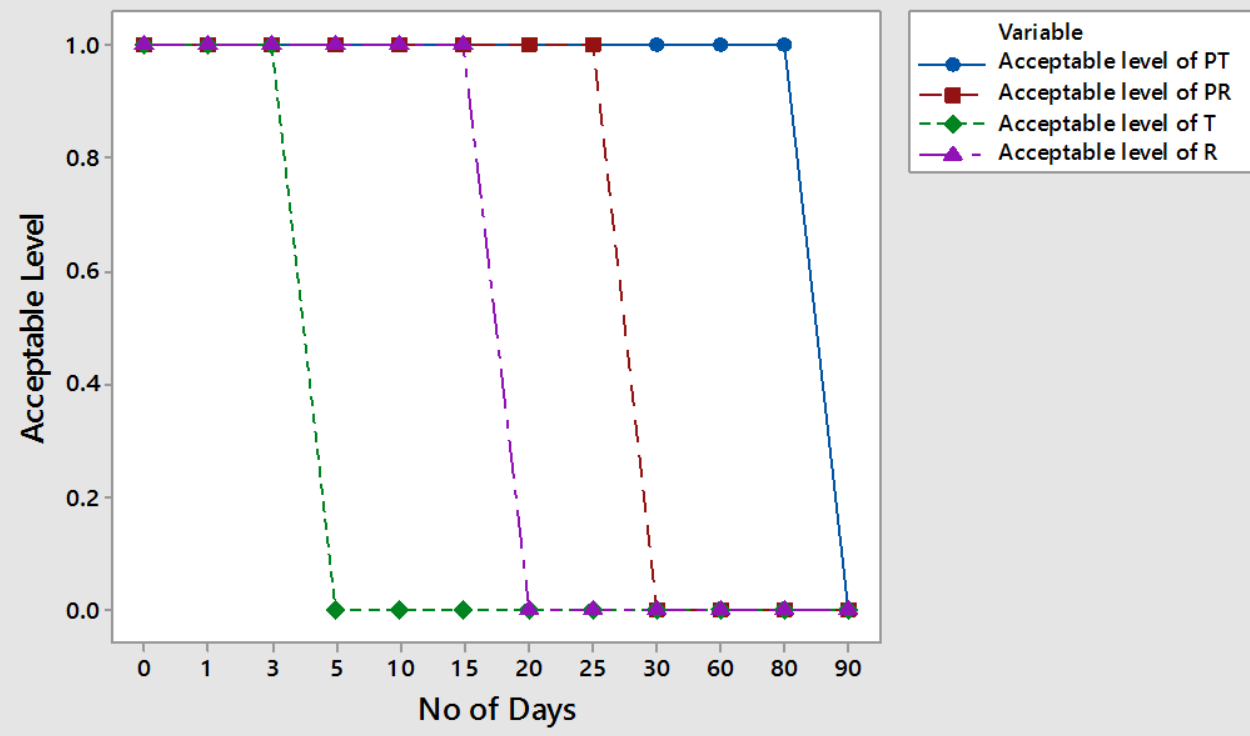

Figure 2: Line Plot of Acceptable level for Yeast and mold test of samples with different treatments PT-With preservative stored in room temperature

$\boldsymbol{P R}$ - With preservative stored in refrigerator

T- Without preservative stored in room temperature

$\boldsymbol{R}$ Without preservative stored in Refrigerator

Table 2: Chemical Composition of the product

\begin{tabular}{|l|l|}
\hline Constituent & Value \\
\hline Carbohydrates (by difference) & $65.16 \pm 2.01 \%$ \\
\hline Protein & $0.14 \pm 0.08 \%$ \\
\hline Fat & $0.12 \pm 0.02 \%$ \\
\hline Fiber & $0.14 \pm 0.07 \%$ \\
\hline Moisture & $34.07 \pm 1.01 \%$ \\
\hline Ash & $0.37 \pm 1.15 \%$ \\
\hline Iron & $3.55 \mathrm{ppm}$ \\
\hline Zinc & $1.79 \mathrm{ppm}$ \\
\hline Manganese & $1.58 \mathrm{ppm}$ \\
\hline Sodium & $459.5 \mathrm{ppm}$ \\
\hline Potassium & $989.92 \mathrm{ppm}$ \\
\hline pH value & 4.0 \\
\hline o Brix value & 30 \\
\hline Energy & $262.28 \mathrm{Kcal} / 100 \mathrm{~g}$ \\
\hline
\end{tabular}

Each value represents the means of three estimations in wet basis.

Dessert Sample was analyzed for six minerals and it showed significant amount as dessert (Table 2). Potassium content was reported as $989.92 \mathrm{ppm}$ in samples as highest content among checked six minerals. Sodium was $459 \mathrm{ppm}$ while Iron was ranked as 3.55ppm, Zinc content presented as $1.79 \mathrm{ppm}$. Value of Manganese as trace element was $1.58 \mathrm{ppm}$ which was showed lowest amount among analyzed six minerals of the dessert. 
This product has low ${ }^{\circ}$ brix value as 30 which is usually consider equivalent to the percentage of sucrose (sugar).

In order for a product to be shelf stable without refrigeration, it need the product to be at high ${ }^{\circ}$ brix. In other words it represents that there is sufficient dissolved solids (fruit pulp, together with sugar) and an insufficient amount of water in the product which is not enough to allow bacterial growth. But with the high ${ }^{\circ}$ brix product contains more calorie So the purpose of the preservation has done through minimum amount of preservatives in this product to minimize caloric value.

As shown in the proximate analysis, energy from $100 \mathrm{~g}$ of the product is $262.28 \mathrm{Kcal}$. Compared to fruit jellies which prepared by pectin as plant-based gelling agent (Tesco Fruit Jellies 200G), this Kithul dessert has more nutrients, low calories, low carbohydrate and considerable amounts of minerals. This is a cost-effective product which can earn a considerable profit when introduced to the market as a nutritious dessert.

At present, Sri Lankans use Kithul flour only for preparation of few traditional food items, such as 'Kithul Thalapa' and 'Dodol' (a sweet meat) (Seneviratne, 2011). It is famous in rural areas in Sri Lanka. Gel forming ability is an important functional property of Kithul flour. This property can be used in the food industry not only for production of jellies, but also for several other applications including jams and jellies. Gel forming ability and the medicinal value of Kithul flour make it a valuable ingredient in food industry and Ayurvedic drugs.

\section{CONCLUSION}

Because of the high necessity due to number of industrial applications, a huge demand on few well-known plant based gelatinizing agent in food manufacturing. Therefore it is creating requirement on new sources for the continuous supply as commercially viable source for this requirement. The aim of the work reported herein as to undertake a comprehensive investigation on the better formulation and chemical properties of a fruit based dessert using flour obtained from Kithul (Caryota urens) tree as introducing gelling agent for food industry has succeed with the results of both sensory and proximate evaluation. It has reported 262.28 $\mathrm{Kcal} / 100 \mathrm{~g}$ of energy with low fat and low total soluble solids.

\section{ACKNOWLEDGEMENT}

The corresponding author thanks her dearest parents Mr \& Mrs Wijesinghe for being the spirit of her education. And her special thanks to both helpful supervisors Dr Indira wicramasinghe and Dr K.H Saranandha for great guidance.

The authors thank the University of Sri Jayewardenepura, Sri Lanka for providing the financial assistance (Grant No: ASP/06/RE/SCI/2012/04) for this study.

\section{REFERENCES}

APAC Chemical Corporation, produt; sorbates, http://www.apacchemical.com/sorbates.htm, last visited on 2014.09.20

Association of official Analytical chemistry (AOAC) (2000). Official methods of analysis of AOAC International, volume 1 .

GMIA. (2012) Gelatin Hand book, Gelatin Manufacturers Institute of America, Inc., New York, NY.

Institute of Food Research; Jelly The Wobbly Science www.ifr.ac.uk/jellyvision/jellyfacts.html , Visited last on 08.08.2014.

Julia F. Morton (1987). Wood-Apple: Fruits of warm climates, ISBN: 0-9610184-1-0, p. 190-191.

Komate Rammaya, Voon Qi Ying and Abdul Salam Babji (2012) Physicochemical Analysis of Gelatin Extracted from Mechanically Deboned Chicken Meat (MDCM) Residue, National University of Malaysia, Malaysia.; International Journal of Food, Nutrition \& Public Health Vol. 5 No. 1/2/3, 
Minister of Healthcare, Nutrition \& Uva Wellassa Development (2004) Food Act No. 26 of 1980; Food (Additives- Preservatives) Regulations - 2004.

Morrison .N.A., Sworn .G., Clark .R.C.,Y.L. Chen,T. Talashek (1999) Gelatin alternatives for the food industry; Progr Colloid Polym Sci (1999) 114 : 127-131, Springer-Verlag,.

Mr. Pramod Pansare,; Preparation of Wood Apple Jelly Community food processing unit, Vigyan ashram, Pabal, Tal- Shirur, Dist- Pune

Nahar, K. (2015). Castor Bean (Ricinus communis L.) - A Biofuel Plant: Morphological and Physiological Parameters Propagated from Seeds in Bangladesh. Asian Business Review, 2(2), 6466. Retrieved fromhttp://journals.abc.us.org/index.php/abr/article/view/Nahar

Orwa ,C., Mutua, A. , Kindt, R. , Jamnadass, R., Simons, A., (2009) Arecaceae L;.Caryota urens. Agroforestree Database: a tree reference and selection guide version 4.0. (http://www.worldagroforestry.org/af/treedb/) visited on 2013.10.02.

Rajyalakshmi , P (2004) Caryota palm sago O A potential get underutilized natural resource for modern starch industry. Naturakl product redience vol 3(3), pp144 -149 (May-June 2004).

Seneviratne, M.A.P.K. (2011) Unpublished phd thesis on "Utilization of indigenous knowledge for the uplistment of Kithul in Sri Lanka, 219, 217-222.

Shah, M., Zhang, S., \& Liu, T. (2015). Whitefly, Host Plant and Parasitoid: A Review on Their Interactions. Asian Journal Of Applied Science And Engineering, 4(1), 48-61. Retrieved fromhttp://journals.abc.us.org/index.php/ajase/article/view/10.5

Shyni .K., Hema. G.S., Ninan .G., Mathew .S., Joshy .C.G., Lakshmanan .P.T.(2014) Isolation and characterization of gelatin from the skins of skipjack tuna (Katsuwonus pelamis), dog shark (Scoliodon sorrakowah), and rohu (Labeo rohita), Food Hydrocolloids 39 (2014) 68e76, www.elsevier.com/locate/foodhyd. Visited last on 20.08.2014

Sri Lanka standard Institution; SLS 586:1982 (Mango juice-sugar content for the product)

Sri Lanka standard Institution; SLS 729:1985 (Fruit juice-Microbial limitation)

Tesco Fruit Jellies 200G, http://www.tesco.com/groceries/product/details/?id=268378919 last visited on 2014.11.20

Wealth of India (1992) A dictionary of Indian raw materials and industrial product Vol.3. Publications and Information directorate. Council of Scientific and Industrial Research, New Delhi,vol 3 ca -ci, pp 322, 321-324.

Source of Support: Nil, Conflict of Interest: None Declared

This article is is licensed under a Creative Commons Attribution-NonCommercial 4.0 International License.

Attribution-NonCommercial (CC BY-NC) license lets others remix, tweak, and build upon work non-commercially, and

although the new works must also acknowledge \& be non-commercial. 